\title{
Logics of Educational Stratification: A Cross-National Map of Educational Inequality
}

\author{
Raphaela Schlicht-Schmälzle ${ }^{1}$ and Kathrin Ackermann ${ }^{2}$ \\ ${ }^{1}$ Department of Politics and Public Administration, University of Konstanz, P.O. Box D 79, Universitaetsstraße 10, \\ 78464 Konstanz, Germany \\ ${ }^{2}$ Department of Politics and Public Administration, University of Konstanz, P.O. Box D 84, Universitaetsstraße 10, \\ 78464 Konstanz, Germany \\ Correspondence should be addressed to Raphaela Schlicht-Schmälzle, raphaela.schlicht-schmaelzle@uni-konstanz.de
}

Received 21 December 2011; Accepted 27 February 2012

Academic Editor: M. Brynin

Copyright ( $) 2012$ R. Schlicht-Schmälzle and K. Ackermann. This is an open access article distributed under the Creative Commons Attribution License, which permits unrestricted use, distribution, and reproduction in any medium, provided the original work is properly cited.

Equality of education is often seen as the fundament of the overall equality of opportunity in modern societies. However, no reliable and comprehensive cross-national comparison of educational inequality hitherto exists. The aim of the present paper is to provide a cross-national comparative outline of diverse dimensions of educational inequality in the OECD world. We estimate the effects of three highly influential aspects of socioeconomic background on educational achievement in each OECD country in order to create a ranking of educational inequality in 30 capitalist countries. The central finding is that we indeed cannot identify a single cross-national ranking but three dimensions of education inequality: educational inequality based on economic, educational, and migration background at home. Capitalist economies thus do not only differ with regard to the degree of inequality but, first and foremost concerning the predominant patterns of inequality and the main distributive keys.

\section{Introduction}

Equality of educational opportunity is a widely accepted indicator of social mobility in societies [1]. Although, equality of opportunity in education has been often discussed in social science research over the last century, cross-nationally comparative contributions remain rather scarce. This is astonishing; especially against the background that educational equality is often seen as a prerequisite of societal cohesion, economic performance, and democratic stability [2-4]. Therefore, the present paper provides a systematic comparison of the patterns of educational inequality in 30 capitalist economies (OECD member states). Our core thesis is that countries cannot be described as generally unequal with regard to education but that we have to consider the concrete patterns of inequality. In this regard, Kerckhoff et al. [5, page 283] state that "[i]t is not enough to say that two societies are generally alike or different in their overall amounts of mobility (total, structural, or circulation). We need to look at the patterns of mobility." Building on the theoretical assumptions of Eyal et al. [6] that different societies follow different logics of distribution, we expect that economic, educational, and migration background at home are differently important for educational stratification in different countries. Thus, different societies follow different distributive keys.

For at least three reasons it is relevant to consider educational inequality from a macrocomparative perspective. First, education is seen as an essential precondition or even as a necessary condition for the functioning of democracy $[3,7,8]$. According to modernization theory a high societal level of education enforces democracy via the development of a democratic culture [7, page 44]. Various studies find a positive effect of higher education on the trust in political institutions, the belief in democratic values and practices and the willingness to participate in politics $[3,9]$. Second, education can be seen as a foundation of meritocracy in modern knowledge societies. Meritocratic values discourage a socially based allocation of public goods and favour one based on individual capabilities and effort instead [10]. 
Moreover, when social inequalities are formed during school education, an allocation of goods by principles of effort and capability is impeded in later curricular stages [11-13]. Social inequality of education is thus a precondition of further inequalities and an obstacle to social mobility $[4,14]$. Third, the wide-ranging education of a society has been a major indicator of modernization processes [3]. A society's investment in education is considered to be a prerequisite to future economic and technical competitiveness as well as of socioeconomic development [15, page 3], [16, page 88]. According to Blossfeld und Shavit [17] the transformation of the labour market from the first to the second and finally to the third sector causes economic demands for higher levels of education. The demand for more equality of opportunity is thus also a consequence of a demand for better skilled employees (cp. [18, page 173]). The dependence of educational attainment on social background, rather than on individual capabilities, is judged as wasted human capital [2].

The previous arguments underline the political and economic relevance of educational inequality and stress the necessity of a macrocomparative perspective on the distinct patterns of educational inequality (cp. $[8,19-26])$. Crossnationally comparative analyses of educational inequality are however solely conducted by Blossfeld and Shavit [17], Ammermüller [27], Barone [28], Pfeffer [29], Schütz et al. [30], and Schlicht et al. [31]. All these studies are restricted to a single dimension of educational inequality at a single point in time. Though, a broad and reliable cross-national ranking of educational inequality does not exist yet. Against this background the paper aims to enrich a traditional sociological research topic by a macrocomparative perspective to gain a comprehensive image of the degrees and dimensions of educational inequality in modern capitalist economies.

The paper is structured as follows. In the next section, we elaborate on the concept of educational inequality and on our central thesis. The third section addresses our methodological procedure. Subsequently, we display our results and thereby provide a map of diverse dimensions of educational inequality in modern capitalist nations. The paper concludes with a discussion and an outlook on future research.

\section{Macrosocietal Logics of Educational Stratification}

Educational inequality is usually defined as the dependence of individuals' educational achievement on their social background [32, page 3]. Educational sociology mainly focuses on the relationship between parental socioeconomic status and children's achievement of capabilities or their achievement of specific educational certificates [29, page 543]. However, parental socio-economic status is composed of a variety of different aspects summarized by Bourdieu's [33] capital forms. The relative importance of these background aspects for educational mobility is hitherto unexplored. In the following we focus on three highly influential aspects of parental socioeconomic background: parental economic, educational, and migration status. A large body of social science literature has established these aspects of socioeconomic background as robust and highly influential

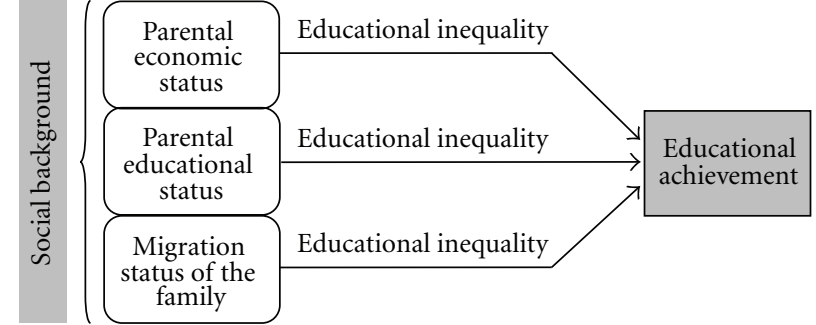

FIgURE 1: Dimensions of educational inequality.

determinants of children's educational achievement [34-36]. Therefore, it is necessary to consider their distinct impact on educational achievement separately (cp. [37]). Thereby we can provide a broad image of the different dimensions of educational inequality and a comprehensive picture of how different aspects of social background determine educational achievement (cp. Figure 1). Our main thesis builds on Eyal et al.'s [6] statement that the relevance of these resources at home for social reproduction varies between societies: different countries follow different distributive keys.

First, according to Ehmke and Siegle [38, page 523] parental economic status-like income, occupational status of the parents, or household possessions-can create an environment, which is supportive for educational achievements. Parents with a high amount of economic resources are interested in preserving this status for their children and therefore support them in reaching high levels of education $[17,34$, 39-47]. The financial background of a family moreover represents one of Bourdieu's [33, page 185] three capital forms that are central for the definition of socio-economic status: economic capital.

Second, children from families with high levels of parental educational status develop cultural competences and values that are highly beneficial for their own educational career $[43,47]$. Educational resources at home are often measured by school certificates or a university degree of the parents [33, page $186 \mathrm{ff}$.]. A variety of studies illuminated the relevance of parental educational status for children's educational achievements [17, 28, 35, 44, 48]. Parental educational status moreover is one aspect of Bourdieu's [33, page 186] broader concept of cultural capital.

Third, a further aspect of children's socio-economic background that is often shown as highly important for their educational achievement is the migration status of the family. In Western societies with high shares of international migration this aspect becomes more and more important for equality of opportunity [49]. A variety of studies show for instance a negative impact of a migration status on educational achievement $[36,50,51]$. Nevertheless, the causal link between migration background and societal success (e.g., educational achievement) is still unsettled. It is disputable whether migration background is just one aspect of lacking cultural knowledge (cultural capital). Schlicht-Schmälzle and Möller [52] however show that the negative impact of migration background on educational achievement remains stable even when controlling for parental educational status 
as an aspect of cultural capital. This indicates that migration status is independent from economic and educational background. It may thus be an indicator for lacking social capital. Social capital is defined by Coleman [53, page 300] as "the set of resources that inhere in family relations and in community social organization and that are useful for cognitive or social development of a child or young person. These resources differ for different persons and can constitute an important advantage for children and adolescents in the development of their human capital." The positive impact of social capital on educational achievement is confirmed by several empirical studies $[37,54,55]$. Similarly various studies found evidence for the thesis, that immigrants have lower levels of social capital [56-58]. Reyneri and Fullin [59, page 35] explicitly state: "The fact that highly educated second generation immigrants still suffer serious labour market disadvantages has been ascribed just to their lack of host country-specific social capital." This means that the failing educational success of migrants has to be referred to lacking social capital when parental economic and educational status is controlled for. In families with migration background the integration in social networks and community social organizations is often lacking and this may explain inequalities of opportunities between migrants and natives. As a matter of course the broad concept of social capital cannot be covered by individuals' migration status. The literature on children's social capital discusses various aspects of within and without family social capital (cp. [55]) but there is no distinct concept of social capital in childhood. Moreover, PISA studies strongly neglect the measure of individuals' social capital at home. However, migration background has been shown as an indicator of socioeconomic background, which is important for children's educational success. Therefore, we examine its impact as an indicator of ethnic resources at home (which can be seen as an indicator of social capital when cultural competences are controlled for).

To sum up, an impressive stock of sociological and educational research shows that economic, educational, and migration background of the family have an impact on individuals' educational achievements. The goal of this present paper is to describe and compare educational inequality cross-nationally: how do these three central aspects of socioeconomic background affect educational achievement in industrialised capitalist countries? We expect different and rather independent dimensions of educational inequality depending on the distinct aspects of family background (parental economic, educational, and migration status) whose relevance for educational achievement may vary between countries (cp. [5], page 283). According to Eyal et al's [6] thesis of the "logics of distributions," societies have certain distributive keys that are responsible for the allocation of collective goods. Eastern European countries are despite their low economic standards often characterized by high levels of societal education: "Since state socialism constrained the development of a class of private proprietors (economic capital) in Central Europe, it is cultural bourgeoisie which has assumed the historic mission of creating bourgeois society and a capitalist economic order" [6, page 9]. Educational background thus acts as a main distributive key in those countries [31]. We build on these arguments and suppose that the importance of different background dimensions for the achievement of education differs between capitalist societies. In other words, we assume that the predominant logic of (educational) stratification varies between countries [60, page 665]. Accordingly, the country rankings should differ with regard to the patterns of educational inequality.

\section{Methods, Data, and Measuring}

3.1. Methods. The main question of this study is how the OECD nations differ with regard to the degree and patterns of educational inequality. The following models (1)-(4) intend to illustrate the derivation of our final regression models (Final Model (1)-(3)). In order to identify the national degrees of social inequality in education, we run country-specific OLS regressions illuminating the effect of individual $(i)$ social background variables on individual educational performance $(P)$ in a specific OECD country $(j)$. We decided to estimate separate, country-specific OLS regressions instead of a multilevel model for reasons of efficiency. If the number of observations on the first stage (ca. 200,000 pupils per PISA wave) is much higher than the number of observations on the second stage (30 countries), a "separatesubsample" model is more efficient than a "pooled-sample" model [61]. Since we do not test any explaining macrovariables in this paper, we only estimate the first stage of such a two-stage "separate-subsample" model. As we aim for a broad and comprehensive overview of diverse types of educational inequality we focus on various indicators of social background. We estimate the effects of individuals' economic $(e)$, educational $(c)$, and migration $(m)$ background variables on their educational achievement, each effect controlled by the others in the same model and by individuals' gender $(g)$ :

$$
P_{i j}=\alpha_{j}+\beta_{e j} \cdot x_{e i j}+\beta_{c j} \cdot x_{c i j}+\beta_{m j} \cdot x_{m i j}+\beta_{g j} \cdot x_{g i j}+\epsilon .
$$

The regression coefficients of the social background variables $\left(\beta_{e}, \beta_{c}\right.$, and $\left.\beta_{m}\right)$ show the degree of educational inequality. The stronger the effect of a certain social background variable, the higher is the degree of educational inequality based on this distributive key.

To assure the country-specific effects of the singlebackground variables on educational achievement, we estimate the effects on three measures of educational achievement (mathematics $(\mathrm{M})$, reading $(\mathrm{R})$, and science $(\mathrm{S})$ ). Thus we run three models for each country elucidating the effect of social background indicators on diverse measures of educational achievement:

$$
\begin{aligned}
P_{\mathrm{M} i j}= & \alpha_{\mathrm{M} j}+\beta_{\mathrm{M} e j} \cdot x_{e i j}+\beta_{\mathrm{M} c j} \cdot x_{c i j} \\
& +\beta_{\mathrm{M} m j} \cdot x_{m i j}+\beta_{\mathrm{M} g j} \cdot x_{g i j}+\epsilon, \\
P_{\mathrm{R} i j}= & \alpha_{\mathrm{R} j}+\beta_{\mathrm{R} e j} \cdot x_{e i j}+\beta_{\mathrm{R} c j} \cdot x_{c i j} \\
& +\beta_{\mathrm{R} m j} \cdot x_{m i j}+\beta_{\mathrm{R} g j} \cdot x_{g i j}+\epsilon, \\
P_{\mathrm{S} i j}= & \alpha_{\mathrm{S} j}+\beta_{\mathrm{S} e j} \cdot x_{e i j}+\beta_{\mathrm{S} c j} \cdot x_{c i j} \\
& +\beta_{\mathrm{S} m j} \cdot x_{m i j}+\beta_{\mathrm{S} g j} \cdot x_{g i j}+\epsilon .
\end{aligned}
$$


Furthermore we calculate all models for three points in time $(2003,2006$, and 2009) in order to check if the dimensions are stable over time. As an example, we display the final models for individuals' mathematic achievement in a specific country.

\section{Final Model 1:}

$$
\begin{aligned}
P_{\mathrm{M} 2003 i j}= & \alpha_{\mathrm{M} 2003 j}+\beta_{\mathrm{M} 2003 e j} \cdot x_{e i j}+\beta_{\mathrm{M} 2003 c j} \cdot x_{c i j} \\
& +\beta_{\mathrm{M} 2003 m j} \cdot x_{m i j}+\beta_{\mathrm{M} 2003 g j} \cdot x_{g i j}+\epsilon .
\end{aligned}
$$

Final Model 2:

$$
\begin{aligned}
P_{\mathrm{M} 2006 i j}= & \alpha_{\mathrm{M} 2006 j}+\beta_{\mathrm{M} 2006 e j} \cdot x_{e i j}+\beta_{\mathrm{M} 2006 c j} \cdot x_{c i j} \\
& +\beta_{\mathrm{M} 2006 m j} \cdot x_{m i j}+\beta_{\mathrm{M} 2006 g j} \cdot x_{g i j}+\epsilon .
\end{aligned}
$$

Final Model 3:

$$
\begin{aligned}
P_{\mathrm{M} 2009 i j}= & \alpha_{\mathrm{M} 2009 j}+\beta_{\mathrm{M} 2009 e j} \cdot x_{e i j}+\beta_{\mathrm{M} 2009 c j} \cdot x_{c i j} \\
& +\beta_{\mathrm{M} 2009 m j} \cdot x_{m i j}+\beta_{\mathrm{M} 2009 g j} \cdot x_{g i j}+\epsilon .
\end{aligned}
$$

In sum, we estimate nine OLS regression models per country: the effects of social background indicators on three measures of educational achievement in three points in time. Each model finally reveals three indicators of social inequality in education per country. Since we reestimate each model for three measures of educational achievement and for three points in time we finally gain 27 indicators of educational inequality for each country. These indicators provide a comprehensive outline of the country rankings regarding the degrees of educational inequality. However, can this picture be reduced to a more efficient description of educational inequality? By performing an exploratory factor analysis we investigate to how many and to which dimensions the 27 indicators of educational inequality can be reduced. This approach clarifies if we have to distinguish between different dimensions of educational inequality which are stable over diverse measures of educational achievement and time.

3.2. Data and Measuring. In order to conduct a systematic cross-national comparison of the degrees of educational inequality in the OECD countries, we use the PISA data 2003, 2006, and 2009. (The abbreviation "PISA" stands for "Program for International Student Assessment," a program that is enforced by the Organisation for Economic Cooperation and Development (OECD). PISA data is also available for 2000 . However, the survey of 2000 is composed by quite different variables what makes it difficult to compare the effects of social background variables between 2000 and 2003/ 2006/2009.) Why do we limit our analysis to industrialised countries? We are interested in how countries with high socioeconomic preconditions, depending on the principles of meritocracy and the market economy differ with regard to their inequality structures. The PISA data contain information about the social background and the educational achievement of more than 200,000 pupils at the age of 15 years.

In accordance with Jacobs [62], we focus on inequality in the education process. Thereby, individuals' educational performance is measured by their achievement of capabilities in three subjects: reading, mathematics, and science. The PISA data provide five plausible values (PVs) on each of these school subjects. Following Levels et al. [63, page 841] we apply the mean of the five plausible values to measure individuals' educational achievement in a particular subject. (The authors will provide the number of participants and the gender distribution as well as the mean scores of the plausible values for all countries on demand.)

There are various variables that can be applied to measure the three family resources (economic, educational, and migration backgrounds). For several reasons, we however only focus on a single measure for each background dimension. First, different measures for one and the same dimension are often strongly correlated what impedes the inclusion of all these variables in the same regression model. Second, PISA indeed provides a variety of items that can be considered as measures for different background dimensions. However, it does by far not cover all possible aspects of socio-economic background. Since we are not interested in a comprehensive concept specification of socio-economic background, we stick to single but tested and robust measures of children's economic, educational, and migration background.

First, the parental economic status of a child is measured by an index called household possessions that includes items like the presence of a study desk or access to the internet at home [63, page 843]. The higher the score of home possession, the higher we evaluate the parental economic status.

Second, parental educational status of a child is measured by the educational achievement of the parents. We use the "Highest Parental International Standard Classification of Education" which ranges from 0 (preprimary level of education) to 6 (second stage of tertiary education) [64, page 9]. According to Bourdieu [33], this factor describes the aspect of institutionalised cultural capital. Further aspects of cultural capital as the embodied cultural capital are barely included in PISA. There are indeed items in PISA that could measure objectified cultural capital (e.g., number of books at home). They are however highly correlated with our measure of economic capital. Moreover, the definition of what objectified cultural capital is is highly subjective and varies over time. Therefore, we stick to the often tested and robust measure of institutionalised cultural capital that should also cover objectified and embodied aspects of cultural capital.

Third, the migration background of the family is measured by a dummy variable "migration status." The indicator distinguishes between immigrants of the first and second generation $(=0)$ and any other children, which are considered to be native $(=1)$.

Furthermore, we include individuals' gender as a control variable using the boys' category as the reference group.

To avoid problems of multicollinearity in our regression models we calculate Pearson's $r$ for all our independent 
TABLE 1: Effects of families' economic, educational, and migration status on individuals' educational achievement in Germany.

\begin{tabular}{|c|c|c|c|c|c|c|c|c|c|}
\hline & \multicolumn{3}{|c|}{ PISA 2003} & \multicolumn{3}{|c|}{ PISA 2006} & \multicolumn{3}{|c|}{ PISA 2009} \\
\hline & Science & Reading & Mathematics & Science & Reading & Mathematics & Science & Reading & Mathematics \\
\hline Home possessions & $\begin{array}{c}32.85^{* * *} \\
(1.65)\end{array}$ & $\begin{array}{c}31.81^{* * *} \\
1.58)\end{array}$ & $\begin{array}{c}30.31^{* * *} \\
(1.62)\end{array}$ & $\begin{array}{c}19.84^{* * *} \\
(1.55)\end{array}$ & $\begin{array}{c}23.32^{* * * *} \\
(1.69)\end{array}$ & $\begin{array}{c}23.37 * * * \\
(1.52)\end{array}$ & $\begin{array}{c}26.61^{* * *} \\
(1.78)\end{array}$ & $\begin{array}{c}24.00^{* * *} \\
(1.68)\end{array}$ & $\begin{array}{c}24.74^{* * *} \\
(1.76)\end{array}$ \\
\hline $\begin{array}{l}\text { Highest parental } \\
\text { educational status }\end{array}$ & $\begin{array}{c}13.87^{* * *} \\
(0.92)\end{array}$ & $\begin{array}{c}10.74^{* * *} \\
(0.87)\end{array}$ & $\begin{array}{c}11.20^{* * *} \\
(0.90)\end{array}$ & $\begin{array}{c}14.91^{* * *} \\
(0.86)\end{array}$ & $\begin{array}{c}15.07^{* * *} \\
(0.95)\end{array}$ & $\begin{array}{c}13.42^{* * *} \\
(0.85)\end{array}$ & $\begin{array}{c}9.20^{* * *} \\
(0.94)\end{array}$ & $\begin{array}{c}9.30^{* * *} \\
(0.89)\end{array}$ & $\begin{array}{c}7.87^{* * *} \\
(0.93)\end{array}$ \\
\hline Native & $\begin{array}{c}57.05^{* * *} \\
(3.96)\end{array}$ & $\begin{array}{c}55.05^{* * *} \\
(3.77)\end{array}$ & $\begin{array}{c}44.90^{* * *} \\
(3.87)\end{array}$ & $\begin{array}{c}65.20^{* * *} \\
(3.77)\end{array}$ & $\begin{array}{c}55.52^{* * *} \\
(4.13)\end{array}$ & $\begin{array}{c}49.83^{* * *} \\
(3.71)\end{array}$ & $\begin{array}{c}53.89^{* * * *} \\
(3.76)\end{array}$ & $\begin{array}{c}40.31^{* * *} \\
(2.54)\end{array}$ & $\begin{array}{c}46.02 * * * \\
(3.71)\end{array}$ \\
\hline Female pupils & $\begin{array}{c}-12.00^{* * *} \\
(2.56)\end{array}$ & $\begin{array}{c}35.96^{* * *} \\
(2.44)\end{array}$ & $\begin{array}{c}-14.53^{* * *} \\
(2.51)\end{array}$ & $\begin{array}{c}-4.48^{\dagger} \\
(2.54)\end{array}$ & $\begin{array}{c}44.71^{* * *} \\
(2.78)\end{array}$ & $\begin{array}{c}-17.33^{* * *} \\
(2.50)\end{array}$ & $\begin{array}{c}-10.35^{* * *} \\
(2.59)\end{array}$ & $\begin{array}{c}29.30^{* * *} \\
(2.44)\end{array}$ & $\begin{array}{c}-16.67^{* * *} \\
(2.56)\end{array}$ \\
\hline Constant & $\begin{array}{c}403.5^{* * *} \\
(4.39)\end{array}$ & $\begin{array}{c}383.5^{* * *} \\
(4.19)\end{array}$ & $\begin{array}{c}426.4^{* * *} \\
(4.30)\end{array}$ & $\begin{array}{c}398.4^{* * *} \\
(5.01)\end{array}$ & $\begin{array}{c}362.1^{* * *} \\
(5.49)\end{array}$ & $\begin{array}{c}411.7^{* * *} \\
(4.94)\end{array}$ & $\begin{array}{l}405.31^{* * *} \\
(5.14)\end{array}$ & $\begin{array}{c}393.86^{* * *} \\
(4.85)\end{array}$ & $\begin{array}{l}425.87^{* * *} \\
(5.09)\end{array}$ \\
\hline adj. $R^{2}$ & 0.29 & 0.29 & 0.24 & 0.21 & 0.21 & 0.20 & 0.20 & 0.23 & 0.22 \\
\hline$N$ & 4,038 & 4,038 & 4,038 & 4,452 & 4,452 & 4,452 & 4,233 & 4,233 & 4,233 \\
\hline
\end{tabular}

Note: significant effects: ${ }^{\dagger}<0.1,{ }^{*} P<.05,{ }^{* *} P<.01,{ }^{* * *} P<.001$; standard errors in brackets.

variables. None of the independent variables correlate higher than $r=0.42$ (economic and educational status in PISA 2003).

\section{Results}

As described above, we run country-specific multiple regressions in order to identify the influence of families' economic, educational and migration background on the individuals' educational achievement. For each country we estimate the effects on the achievement in three school subjects in three different points in time (nine models per country). Table 1 displays the nine models exemplarily for Germany. It includes the effect of each of the three social background variables on three educational achievement variables in three points in time. More precisely, it contains 27 indicators of educational inequality. All independent variables show a significant impact on the diverse measures of educational achievement. The home possessions (parental economic status) and parental level of education (parental educational status) positively affect the educational achievement. Natives perform better in all subjects. As expected, male pupils are significantly better in mathematics and science, while female pupils do better in reading. Unsurprisingly, all aspects of social background significantly influence individuals' educational achievement in the Germany over all three PISA waves. We conducted this analysis for all OECD countries. (The results for all 30 OECD countries are available from the authors on demand.)

4.1. Multidimensional Logics of Educational Stratification in the Industrialised World. In order to test our central thesis of distinct dimensions of educational inequality, we perform an exploratory factor analysis. We use the 27 regression coefficients we received per country (cp. Table 1 for Germany) as indicators of educational inequality and analyse, how they relate to each other. The exploratory factor analysis confirms the central thesis of this study. While educational inequality is stable over time and over different measurements of educational achievement, the indicators of educational inequality based on the three social background variables are barely associated. The factor analysis revealed six factors with an eigenvalue of $>1$. We assigned the variables in each case to that factor on which it provides the highest factor loading (see Table 2). Even though, variables of the same background dimension are partly assigned to different factors, variables of different social background dimensions are never assigned to the same factor. A first dimension (factor 1) accumulates all effects of parental educational status on different educational outcomes in different PISA waves. All nine effects are accumulated in the same factor (all factor loadings $>0.75$ ).

A second dimension (factor 2) covers all effects of parental economic status on diverse measures of educational achievement in the PISA waves. The nine effects provide factor loadings of $>0.5$ on this factor. Two effects (economic status on mathematic achievement and reading achievement in PISA 2003) show an even higher factor loading on another factor (factor 6). However, their second highest factor loading is also on factor 2 . This indicates that all the nine effects of economic status are strongly associated.

A third dimension describing the effects of the migration status of the family on diverse measures of educational achievement is much more complex. Even though none of the effects of migration status is assigned to a factor describing one of the other background dimensions, the nine coefficients cannot be assigned to one single factor (see Table 2). The assignment of the effect of migration background to a factor varies depending on the educational outcome (mathematics, science, and reading achievement) and depending on the PISA wave (2003, 2006, and 2009). These results indicate that the effect of migration background is indeed independent from other inequalities in education. However, it also shows that we cannot find a distinct factor of inequality based on migration background that is robust over time and over different educational outcomes. The revealed factors vary between mathematic and science achievement on the one hand and reading achievement on the other hand and alter over time. The ambiguous allocation of inequality measures based on the migrations process may be referred to the comparatively new phenomenon of far-reaching migration in 
TABLE 2: Factor-analysis dimensions of educational inequality.

\begin{tabular}{|c|c|c|c|c|c|c|c|c|}
\hline \multicolumn{3}{|c|}{27 Variables (educational inequality) } & \multirow{2}{*}{$\begin{array}{c}\text { Dimension } \\
\text { educational status } \\
\text { Factor } 1\end{array}$} & \multicolumn{2}{|c|}{ Dimension economic status } & \multicolumn{3}{|c|}{ Dimension migration status } \\
\hline $\begin{array}{l}\text { Socioeconomic } \\
\text { background variable }\end{array}$ & Outcome & PISA wave & & Factor 2 & Factor 6 & Factor 3 & Factor 4 & Factor 5 \\
\hline \multirow{9}{*}{$\begin{array}{l}\text { Parental } \\
\text { educational } \\
\text { status }\end{array}$} & Mathematics & 2003 & 0.94 & 0.11 & -0.11 & -0.13 & -0.01 & -0.13 \\
\hline & Readings & 2003 & 0.91 & 0.10 & -0.09 & -0.18 & -0.02 & -0.03 \\
\hline & Science & 2003 & 0.92 & 0.14 & -0.11 & -0.28 & 0.04 & -0.03 \\
\hline & Mathematics & 2006 & 0.94 & -0.12 & 0.12 & -0.18 & -0.11 & -0.03 \\
\hline & Readings & 2006 & 0.90 & -0.09 & 0.12 & -0.21 & -0.18 & 0.06 \\
\hline & Science & 2006 & 0.91 & -0.07 & 0.11 & -0.25 & -0.16 & 0.01 \\
\hline & Mathematics & 2009 & 0.84 & -0.02 & 0.00 & -0.16 & -0.04 & 0.00 \\
\hline & Readings & 2009 & 0.81 & 0.05 & 0.01 & -0.12 & -0.17 & 0.10 \\
\hline & Science & 2009 & 0.77 & 0.13 & -0.01 & -0.15 & -0.12 & 0.07 \\
\hline \multirow{9}{*}{$\begin{array}{l}\text { Parental } \\
\text { economic status }\end{array}$} & Mathematics & 2003 & -0.02 & 0.51 & 0.83 & -0.06 & 0.02 & -0.09 \\
\hline & Readings & 2003 & 0.04 & 0.59 & 0.74 & -0.11 & -0.11 & 0.01 \\
\hline & Science & 2003 & -0.07 & 0.68 & 0.49 & -0.02 & -0.14 & -0.01 \\
\hline & Mathematics & 2006 & -0.07 & 0.86 & 0.10 & 0.08 & 0.21 & -0.19 \\
\hline & Readings & 2006 & -0.04 & 0.87 & 0.07 & -0.13 & 0.02 & -0.10 \\
\hline & Science & 2006 & -0.07 & 0.93 & 0.03 & 0.03 & -0.03 & -0.15 \\
\hline & Mathematics & 2009 & 0.17 & 0.89 & 0.20 & -0.01 & -0.09 & -0.10 \\
\hline & Readings & 2009 & 0.06 & 0.90 & 0.16 & -0.07 & -0.13 & -0.09 \\
\hline & Science & 2009 & 0.13 & 0.90 & 0.16 & 0.03 & -0.18 & 0.02 \\
\hline \multirow{9}{*}{$\begin{array}{l}\text { Migration status } \\
\text { of the family }\end{array}$} & Mathematics & 2003 & -0.19 & -0.04 & 0.11 & 0.35 & 0.87 & 0.03 \\
\hline & Readings & 2003 & -0.28 & -0.07 & -0.05 & 0.71 & 0.61 & 0.05 \\
\hline & Science & 2003 & -0.13 & -0.03 & -0.07 & 0.28 & 0.89 & -0.12 \\
\hline & Mathematics & 2006 & -0.03 & -0.16 & -0.04 & 0.00 & 0.08 & 0.98 \\
\hline & Readings & 2006 & -0.01 & -0.13 & -0.10 & 0.14 & 0.94 & -0.05 \\
\hline & Science & 2006 & -0.01 & -0.16 & -0.02 & -0.03 & -0.18 & 0.96 \\
\hline & Mathematics & 2009 & -0.32 & 0.07 & -0.05 & 0.90 & 0.23 & -0.04 \\
\hline & Readings & 2009 & -0.40 & -0.11 & -0.07 & 0.86 & 0.27 & -0.03 \\
\hline & Science & 2009 & -0.31 & -0.01 & -0.01 & 0.92 & 0.19 & 0.00 \\
\hline
\end{tabular}

Note: Results of Varimax rotation. Principle component analysis.

industrialised countries and the still on-going societal transformation processes related to international migration. Societal structures based on economic and educational resources at home are historically established and therefore rather stable. By contrast, new societal phenomena as migration are unsettled and change over time.

To sum it up, we can identify three independent dimensions of educational inequality: educational inequality based on (1) economic, (2) educational, and (3) migration background. This confirms that capitalist societies differ concerning the logic of stratification. While some countries rank high on the impact of parental economic status on educational achievement, others rank high on educational inequality based on parental educational status or migration background. The distribution of education depends on different distributive keys: parental economic, educational, or migration status. Since the impacts of the same background dimension - at least in the case of parental economic and educational status-on different measures of educational achievement in three different points in time are strongly associated and are accumulated in one dimension by the factor analysis, we can assume reliable and robust measures of at least two dimensions of educational inequality. They represent different dimensions of educational inequality; each dimension stands for one aspect of the socioeconomic background included in the models.

4.2. Patterns of Educational Inequality in 30 Industrialised Countries. Since the main focus of the paper is on the crossnational differences of educational inequality, Figures 2 to 4 display the country rankings of the three dimensions of educational inequality. Due to the strong reliability of the three inequality dimensions we only present the rankings for the effects of the three social background variables on one measure of educational achievement (mathematics) in one point in time (2006). As the results of the factor analysis suggest, the rankings of the effects in 2003 and 2009 on mathematic achievement and the effects in 2003, 2006 and 2009 on reading and science achievement are very similar. Again, the rankings illustrate the independence of the three dimensions of educational inequality. Furthermore, the figures show that on all dimensions the degrees of educational inequality differ significantly between the 30 OECD countries. Despite the shared socio-economic and political 


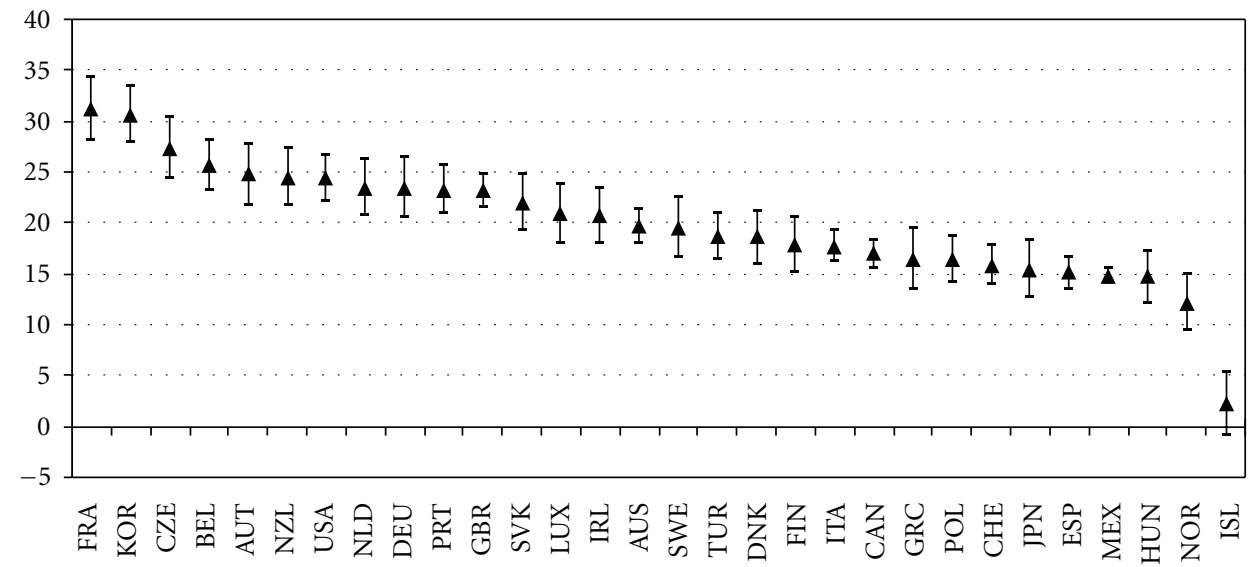

FIGURE 2: Effect of parental economic status on individuals' mathematics achievement and 95\% confidence intervals in 30 OECD countries in 2006 (=educational inequality based on parental economic status).

development of the OECD countries we can observe highly varying inequality structures with regard to both, the degrees and the patterns of inequality.

Figure 2 displays the degrees of educational inequality based on parental economic status in all OECD nation states. First of all the ranking shows that economic background affects educational achievement in all countries (except Iceland), even while controlling for educational and migration background as well as gender. However, the degrees of educational inequality based on parental economic status strongly vary between the countries. The impact of economic background on individuals' educational achievement is highest in France. By contrast, the degree of economic inequality in education is by far lowest in Iceland followed by Norway and Hungary. In those countries economic-social background plays a minor role for school success compared to the rest of the OECD world. Surprisingly, very rich countries as Japan and Norway provide pretty low degrees of educational inequality depending on parental economic status. According to Eyal et al. [6], countries with a rather strong general stock of economic capital should rank high on inequality depending on economic status since this aspect of social background acts as the predominant distributive key. The ranking in Figure 2 however does not substantiate this.

Figure 3 shows the country ranking on the degrees of educational inequality based on parental educational status. Again, parental educational status in all countries shows a positive effect on educational achievement, even though in different degrees. The degree of educational inequality based on educational background is highest in Hungary, Slovakia, Czech Republic, and Poland. All eastern European countries in our sample are accumulated in the top flight of educational inequality based on parental educational status. Thus, parental educational status seems to be systematically more important for educational achievement in the postcommunist world than in Western industrialised countries. This result highly confirms the thesis of Eyal et al. [6] that cultural capital plays a decisive role in post-communist societies, while it is only moderately important in capitalist societies. Moreover it corresponds to the findings of Schlicht et al. [31]. The traditional capitalist societies all rank on a moderate or low level of inequality based on parental educational status.

Finally, Figure 4 presents the degrees of educational inequality based on migration background at home. The migration background does not in all countries significantly affect the achievement of capabilities when controlling for economic and educational background and gender. In Turkey, Hungary, New Zealand, Canada, and USA, there is no significant effect of migration background. Some effects in this ranking must be considered with caution: Only $0.02 \%$ of the Korean pupils ( 1 student) in the sample are immigrants. Therefore the estimation is quite unreliable, as the wide confidence interval indicates. The same goes for the figures of Poland, Slovakia, and Japan. The lowest degree of inequality based on migration background can be found in Canada, USA, and Great Britain. In these countries, existing negative effects of migration status depend on educational knowledge (what is controlled for by parental educational status) (cp. [52]). The highest effect of being native exists in Finland and Mexico. In those countries migration background has a very low or even negative effect on educational achievement when controlling for parental economic and educational status and gender. This indicates that migration status in these countries is an indicator for lacking social integration (social capital) (cp. [56-59]). Remarkably, the traditional immigration countries show the lowest degrees of inequality based on migration background. This suggests that the traditional immigration countries have a head start in integrating foreigners in their education system.

\section{Conclusion}

The central aim of this paper was to provide a crossnational comparative and comprehensive map of educational inequality. Our core thesis was that national societies differ with regard to their logics of educational stratification. This 


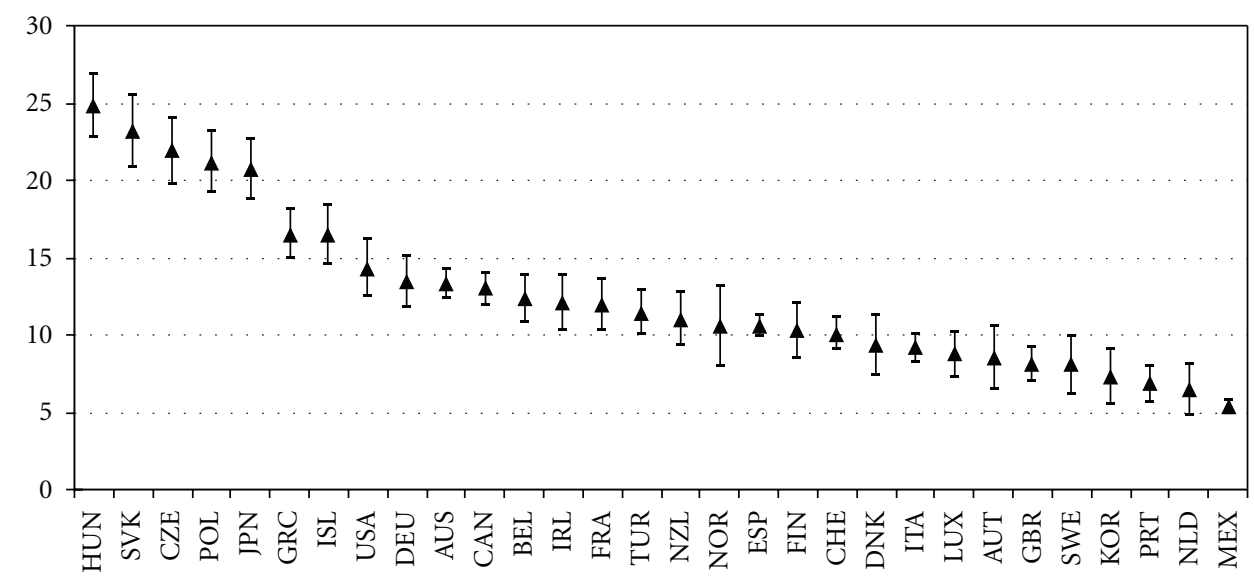

FIGURE 3: Effect of parental educational status on individuals' mathematics achievement and 95\% confidence intervals in 30 OECD countries in 2006 (=educational inequality based on parental educational status).

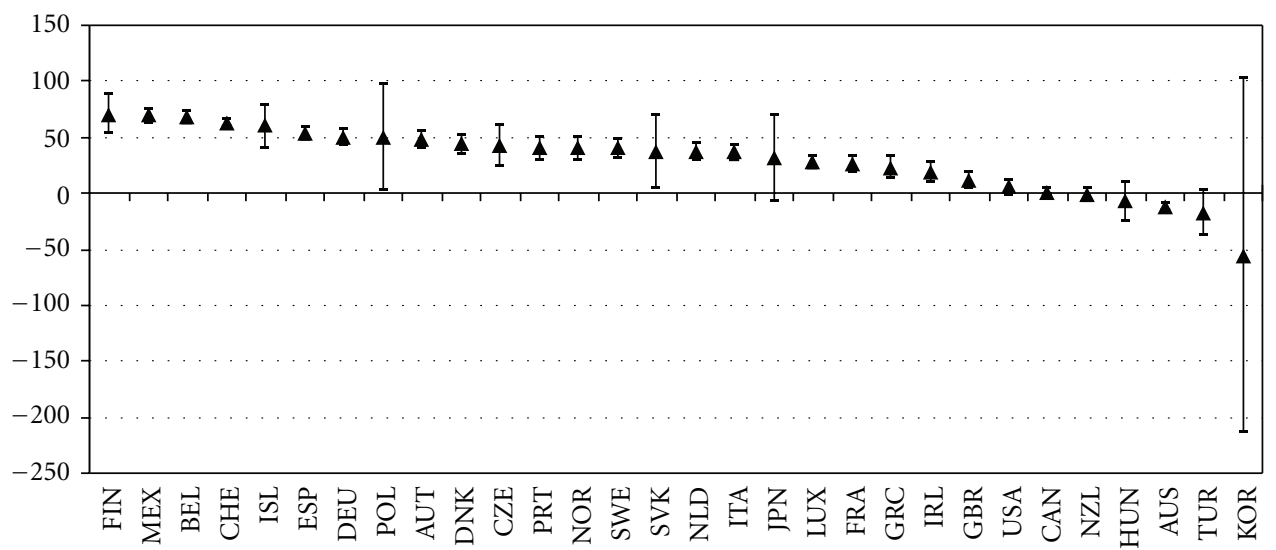

FIGURE 4: Effect of migration status of the family on individuals' mathematics achievement and 95\% confidence intervals in 30 OECD countries in 2006 (=educational inequality based on migration status of the family).

thesis is supported by our findings: The country rankings on educational inequality highly differ with regard to the dimension of educational inequality, which is inequality based on parental economic, educational, or migration status. Thus countries cannot be characterized as generally equal or unequal. All societies are characterized by different patterns of inequality. Therefore, we can conclude in line with Eyal et al. [6] that different societies follow different logics of educational distribution and have different distributive keys. While in some countries, economic resources act as the main distributive keys, in others education or migration background is more important for mobility.

In the previous analyses we focused on highly relevant and often tested indicators of socioeconomic background which can also be seen as aspects of the three capital forms established by Bourdieu [33]: economic, cultural, and social capital. Bourdieu [33] himself argues that the capital forms are alternative sources of power and privilege. They are relatively independent from each other in shaping the system of social stratification. Our results therefore provide empirical evidence to one of Bourdieu's main theses. It is however unquestionable that our measures of socio-economic status only partly represent the three capital forms. Some of the capital forms are rather fuzzy and broad concepts, which include various different aspects of social background that are partly interrelated (and though cannot be simultaneously included in a regression analyses) or that are not included in the PISA data sets. Especially, the concept of social capital is not at all covered by variables in the PISA data. Indeed, the migration status of the family is often-not only in this study - shown as a highly influential social background factor on children's educational achievement. However, it is still unclear whether migration background is an indicator of lacking cultural or social capital, or both. Further crossnationally comparative research should be encouraged to widen the scope of our results by examining further indicators of Bourdieu's [33] capital forms. Especially, the rather diffuse concept of children's social capital at home has to be regarded more intensely from a comparative perspective. Nevertheless the analyses in this paper clearly show that different dimensions of the social background are of varying importance for educational achievement in different countries.

Most importantly, our results raise the question of the reasons of different logics of educational distribution in different societies. This paper, however, explicitly focuses on 
an explorative analysis of diverse logics of educational distribution. We therefore leave the analysis of macrosocietal causes of diverse patterns of educational inequality to future research. Theories explaining inequality structures in different societies are rather scarce. Eyal et al.'s [6] classification of the differing importance of the capital forms in postcommunist and traditional capitalist societies has to be highlighted as an exception, but it can only partly be supported by our findings. Schlicht-Schmälzle and Möller [52] show that educational inequality based on migration background is highly influenced by the patterns of democratic institutions. According to these results majoritarian democracies show weaker inequalities between migrants and natives than consensus democracies (cp. [49]). The complexity of educational inequality elucidated by our study shows that we need a more comprehensive theory on how different societal logics of educational redistribution evolve. It is not sufficient anymore to theorize why countries are more equal or unequal with regard to education and mobility, but it has to be explained why countries provide different patterns of educational inequality and different distributive keys. Therefore future research has to focus on the macrosocietal explanation of diverse dimensions of educational inequality. The awareness of different rather independent dimensions of educational inequality also leads to the question of their relevance for societies. Future research on the effects of educational inequalities should elaborate on how diverse dimensions of educational inequality differ with regard to their societal risks and consequences.

In conclusion the results of this paper, which reveal three independent dimensions of educational inequality and their relevance for educational stratification in 30 industrialised countries, constitute a starting point for future research. It should concentrate on the reasons and consequences of the presented logics of educational stratification in the industrialised world.

\section{Country Abbreviations}

AUS: Australia
AUT: Austria
BEL: Belgium
CAN: Canada
CHE: Switzerland
CZE: Czech Republic
DEU: Germany
DNK: Denmark
ESP: Spain
FIN: Finland
FRA: France
GBR: Great Britain
GRC: Greece
HUN: Hungary
IRL: Ireland
ISL: Iceland
ITA: Italia
JPN: Japan
KOR: Korea
LUX: Luxembourg

MEX: Mexico

NLD: Netherlands

NOR: Norway

NZL: New Zealand

POL: Poland

PRT: Portugal

SVK: Slovakia

SWE: Sweden

TUR: Turkey

USA: United States of America.

\section{Acknowledgments}

A first draft of the paper was presented at the Annual Conference of the Swiss Political Science Association 2010 and at the Annual Conference of the British Sociological Association 2011. The authors thank all participants in the discussions for their contributions and helpful remarks. Moreover the authors thank Markus Freitag (University of Bern) and Kerstin Martens (University of Bremen) for providing an encouraging environment for the work on this paper.

\section{References}

[1] D. B. Grusky and R. M. Hauser, "Comparative social-mobility revisited-models of convergence and divergence in 16 countries," American Sociological Review, vol. 49, no. 1, pp. 1938, 1984.

[2] J. Handl, "Mehr Chancengleichheit im Bildungssyste," Kölner Zeitschrift für Soziologie und Sozialpsychologie, vol. 37, no. 4, pp. 698-722, 1985.

[3] S. M. Lipset, "Some social requisites of democracy-economic-development and political legitimacy," American Political Science Review, vol. 53, no. 1, pp. 69-105, 1959.

[4] W. Müller and R. Pollak, "Social mobility in West Germany: the long arms of history discovered?" in Social Mobility in Europe, R. Breen, Ed., pp. 77-113, Oxford University Press, Oxford, UK, 2004.

[5] A. C. Kerckhoff, R. T. Campbell, and I. Winfield-Laird, "Social mobility in great Britain and the United States," The American Journal of Sociology, vol. 91, no. 2, pp. 281-308, 1985.

[6] G. Eyal, I. Szelényi, and E. Townsley, Making Capitalism without Capitalists. The New Ruling Elites in Eastern Europe, Verso, London, UK, 1998.

[7] D. Acemoglu, S. Johnson, J. A. Robinson, and P. Yared, "From education to democracy?" American Economic Review, vol. 95, no. 2, pp. 44-49, 2005.

[8] J. S. Coleman, Equality of Educational Opportunity, U.S. Government Printing Office, Washington, DC, USA, 1966.

[9] G. A. Almond and S. Verba, The Civic Culture. Political Attitudes and Democracy in Five Nations, Princeton University Press, Princeton, NJ, USA, 1965.

[10] H. Solga, "Meritokratie-die moderne Legitimation ungleicher Bildungschancen," in Institutionalisierte Ungleichheiten? Stabilität und Wandel von Bildungschancen, P. A. Berger and H. Kahlert, Eds., pp. 19-38, Juventa, Weinheim und München, Germany, 2005.

[11] M. Carnoy and H. M. Levin, Schooling and Work in the Democratic State, Stanford University, Stanford, Calif, USA, 1985.

[12] W. H. Sewell, "Inequality of opportunity for higher education," American Sociological Review, vol. 36, no. 5, pp. 793-809, 1971. 
[13] S. van Zandt Winn, "Social class and income returns to eductaion in Sweden: a research note," Social Forces, vol. 62, no. 4, pp. 1026-1034, 1984.

[14] J. Allmendinger and S. Leibfried, "Education and the welfare state: the four worlds of competence production," Journal of European Social Policy, vol. 13, no. 1, pp. 63-81, 2003.

[15] I. Fägerlind and L. J. Saha, Education and National Development, Butterworth-Heinemann, Oxford, UK, 1989.

[16] P. W. Kingston, "The unfulfilled promise of cultural capital theory," Sociology of Education, vol. 74, pp. 88-99, 2001.

[17] H.-P. Blossfeld and Y. Shavit, "Permanent inequaliteschanges in the impact of social background on educationalopportunity in 13 industrial-nations," Zeitschrift für Pädagogik, vol. 39, no. 1, pp. 25-52, 1993.

[18] J. Allmendinger, C. Ebner, and M. Schludi, "Die bildungspolitische Funktion der Arbeitsverwaltung im Spannungsfeld von betriebswirtschaftlicher Logik und gesamtgesellschaftlicher Verantwortung," in Evidenzbasierte Bildungspolitik: Beiträge der Bildungsökonomie, M. Weiß, Ed., pp. 173-191, Duncker \& Humblot, Berlin, Germany, 2006.

[19] J. Allmendinger, "Verschenkte Chancen. Handlungsspielräume für die Bildungspolitik," Internationale Politik, vol. 59, no. 5, pp. 58-66, 2004.

[20] R. Becker, "Klassenlage und Bildungsentscheidungen," Kölner Zeitschrift für Soziologie und Sozialpsychologie, vol. 52, no. 3, pp. 450-475, 2000.

[21] R. Becker and W. Lauterbach, "Die immerwährende Frage der Bildungsungleichheit im neuen Gewand," in Bildung als Privileg? Erklärungen und Befunde zu den Ursachen von Bildungsungleichheit, R. Becker and W. Lauterbach, Eds., pp. 429-445, VS für Sozialwissenschaften, Wiesbaden, Germany, 2004.

[22] J. Dronkers, "Educational reform in the Netherlands-did it change the impact of parental occupation and education?" Sociology of Education, vol. 66, no. 4, pp. 262-277, 1993.

[23] E. A. Hanushek and J. A. Luque, "Efficiency and equity in schools around the world," Economics of Education Review, vol. 22, no. 5, pp. 481-502, 2003.

[24] H. Mehan, "Understanding inequality in schools. The contribution of interpretative studies," Sociology of Education, vol. 65, pp. 1-20, 1992.

[25] W. Müller, "Ungleichheitsstrukturen im vereinten Deutschland," in Soziale Ungleichheit. Neue Befunde zu Strukturen, Bewußtsein und Politik, W. Müller, Ed., pp. 13-42, Leske and Budrich, Opladen, Germany, 1997.

[26] W. Müller, "Zwischenbilanz der Förderinitiative 'Forschergruppen in der Empirischen Bildungsforschung," in Impulse für die Bildungsforschung. Stand und Perspektiven, $\mathrm{H}$. Mandl and B. Kopp, Eds., pp. 45-53, Akademie, Berlin, Germany, 2005.

[27] A. Ammermüller, "Educational opportunities and the role of institutions," 2005, http://edocs.ub.unimaas.nl/loader/file .asp?id=1071.

[28] C. Barone, "Cultural capital, ambition and the explanation of inequalities in learning outcomes: a comparative analysis," Sociology, vol. 40, no. 6, pp. 1039-1058, 2006.

[29] F. T. Pfeffer, "Persistent inequality in educational attainment and its institutional context," European Sociological Review, vol. 24, no. 5, pp. 543-565, 2008.

[30] G. Schütz, H. W. Ursprung, and L. Woessmann, "Education policy and equality of opportunity," Kyklos, vol. 61, no. 2, pp. 279-308, 2008.

[31] R. Schlicht, I. Stadelmann-Steffen, and M. Freitag, "Educational inequality in the EU: the effectiveness of the national education policy," European Union Politics, vol. 11, no. 1, pp. 29-59, 2010.
[32] W. Müller and D. Haun, "Bildungsungleichheit im sozialen Wandel," Kölner Zeitschrift für Soziologie und Sozialpsychologie, vol. 46, pp. 1-43, 1994.

[33] P. Bourdieu, "Ökonomisches Kapital, kulturelles Kapital, soziales Kapital," in Soziale Ungleichheiten, R. Kreckel, Ed., pp. 183-198, Otto Schwartz \& Company, Göttingen, Germany, 1983.

[34] W. H. Sewell and V. P. Shah, "Socioeconomic status, intelligence, and attainment of higher education," Sociology of Education, vol. 40, no. 1, pp. 1-23, 1967.

[35] P. DiMaggio, "Cultural capital and school success. The impact of status culture participation on the grades of U.S. high school students," American Sociological Review, vol. 47, no. 2, pp. 189201, 1982.

[36] V. J. Roscigno and J. W. Ainsworth-Darnell, "Race, cultural capital, and educational resources: persistent inequalities and achievement returns," Sociology of Education, vol. 72, no. 3, pp. 158-178, 1999.

[37] J. S. Coleman, "Social capital in the creation of human capital," American Journal of Sociology, vol. 94, pp. 95-120, 1988.

[38] T. Ehmke and T. Siegle, "ISEI, ISCED, HOMEPOS, ESCS. Indikatoren der sozialen Herkunft bei der Quantifizierung von sozialen Disparitäten," Zeitschrift für Erziehungswissenschaft, vol. 8, pp. 521-540, 2005.

[39] S. Davies and N. Guppy, "Fields of study, college selectivity, and student inequalities in higher education," Social Forces, vol. 75, no. 4, pp. 1417-1438, 1997.

[40] M. Egerton, "Occupational inheritance: the role of cultural capital and gender," Work, Employment and Society, vol. 11, no. 2, pp. 263-282, 1997.

[41] M. N. Hansen, "Social and economic inequality in the educational career: do the effects of social background characteristics decline?" European Sociological Review, vol. 13, no. 3, pp. 305-321, 1997.

[42] R. M. Hauser, "Progress in schooling," in Social Inequality, K. M. Neckerman, Ed., pp. 271-318, Russell Sage Foundation, New York, NY, USA, 2004.

[43] R. V. Robinson and M. A. Garnier, "Class reproduction among men and women in France: reproduction theory on its home ground," The American Journal of Sociology, vol. 91, no. 2, pp. 250-280, 1985.

[44] R. W. Rumberger, "The influence of family background on education, earnings, and wealth," Social Forces, vol. 61, no. 3, pp. 755-773, 1983.

[45] M. Savage and M. Egerton, "Social mobility, individual ability and the inheritance of class inequality," Sociology, vol. 31, no. 4, pp. 645-672, 1997.

[46] V. Stocké, "Explaining educational decision and effects of families' social class position: an empirical test of the breenfoldthorpe model of educational attainment," European Sociological Review, vol. 23, no. 4, pp. 505-519, 2007.

[47] A. Sullivan, "Cultural capital and educational attainment," Sociology, vol. 35, no. 4, pp. 893-912, 2001.

[48] N. D. de Graaf, P. M. de Graaf, and G. Kraaykamp, "Parental cultural capital and educational attainment in the Netherlands: a refinement of the cultural capital perspective," Sociology of Education, vol. 73, no. 2, pp. 92-111, 2000.

[49] I. Kogan, "New immigrants—old disadvantage patterns? Labour market integration of recent immigrants into Germany," International Migration, vol. 49, no. 1, pp. 91-117, 2011.

[50] R. D. Alba, J. Handl, and W. Müller, "Ethnische Ungleichheit im deutschen Bildungssystem," Kölner Zeitschrift für Soziologie und Sozialpsychologie, vol. 46, no. 2, pp. 209-237, 1994. 
[51] J. Tolsma, M. Coenders, and M. Lubbers, "Trends in ethnic educational inequalities in the Netherlands: a cohort design," European Sociological Review, vol. 23, no. 3, pp. 325-339, 2007.

[52] R. Schlicht-Schmälzle and S. Möller, "Macro-political determinants of educational inequality between migrants and natives in the Western EU," Forthcoming in West European Politics, 2011.

[53] J. S. Coleman, Equality and Achievement in Education, Westview Press, Boulder, Colo, USA, 1990.

[54] T. L. Parcel and M. J. Dufur, "Capital at home and at school: effects on student achievement," Social Forces, vol. 79, no. 3, pp. 881-911, 2001.

[55] J. D. Teachman, K. Paasch, and K. Carver, "Social capital and dropping out of school early," Journal of Marriage and Family, vol. 58, no. 3, pp. 773-783, 1996.

[56] C. L. Bankston and M. Zhou, "Social capital and immigrant children's achievement," in Schooling and Social Capital in Diverse Cultures, B. H. Fuller and E. Hannum, Eds., pp. 1339, Elsevier, Boston, Mass, USA, 2002.

[57] T. Faist, "Migration und der Transfer sozialen Kapitals oder: Warum gibt es relativ wenige internationale Migranten?" in Transnationale Migration, L. Pries, Ed., pp. 63-84, Nomos, Baden-Baden, Germany, 1997.

[58] G. Kao and L. T. Rutherford, "Does social capital still matter? Immigrant minority disadvantage in school-specific social capital and its effects on academic achievement," Sociological Perspectives, vol. 50, no. 1, pp. 27-52, 2007.

[59] E. Reyneri and G. Fullin, "Labour market penalties of new immigrants in new and old receiving West European countries," International Migration, vol. 49, no. 1, pp. 31-57, 2011.

[60] V. Nee, "A theory of market transition: from redistribution to markets in state socialism," American Sociological Review, vol. 54, no. 5, pp. 663-681, 1989.

[61] R. J. Franzese, "Empirical strategies for various manifestations of multilevel data," Political Analysis, vol. 13, no. 4, pp. 430446, 2005.

[62] J. A. Jacobs, “Gender inequality and higher education,” Annual Review of Sociology, vol. 22, pp. 153-185, 1996.

[63] M. Levels, J. Dronkers, and G. Kraaykamp, "Immigrant children's educational achievement in western countries: origin, destination, and community effects on mathematical performance," American Sociological Review, vol. 73, no. 5, pp. 835853, 2008.

[64] Organisation for Economic Cooperation and Development, Classifying Educational Programmes. Manual ISCED-97 Implementation in OECD Countries, Organisation for Economic Cooperation and Development, Paris, France, 1999. 

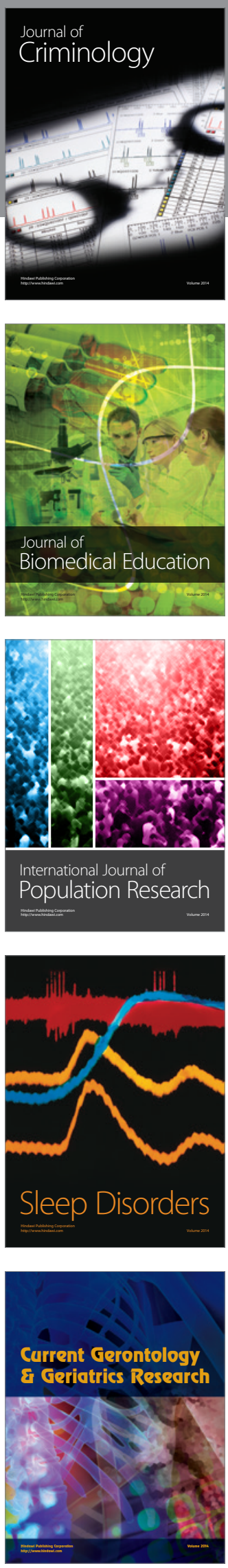
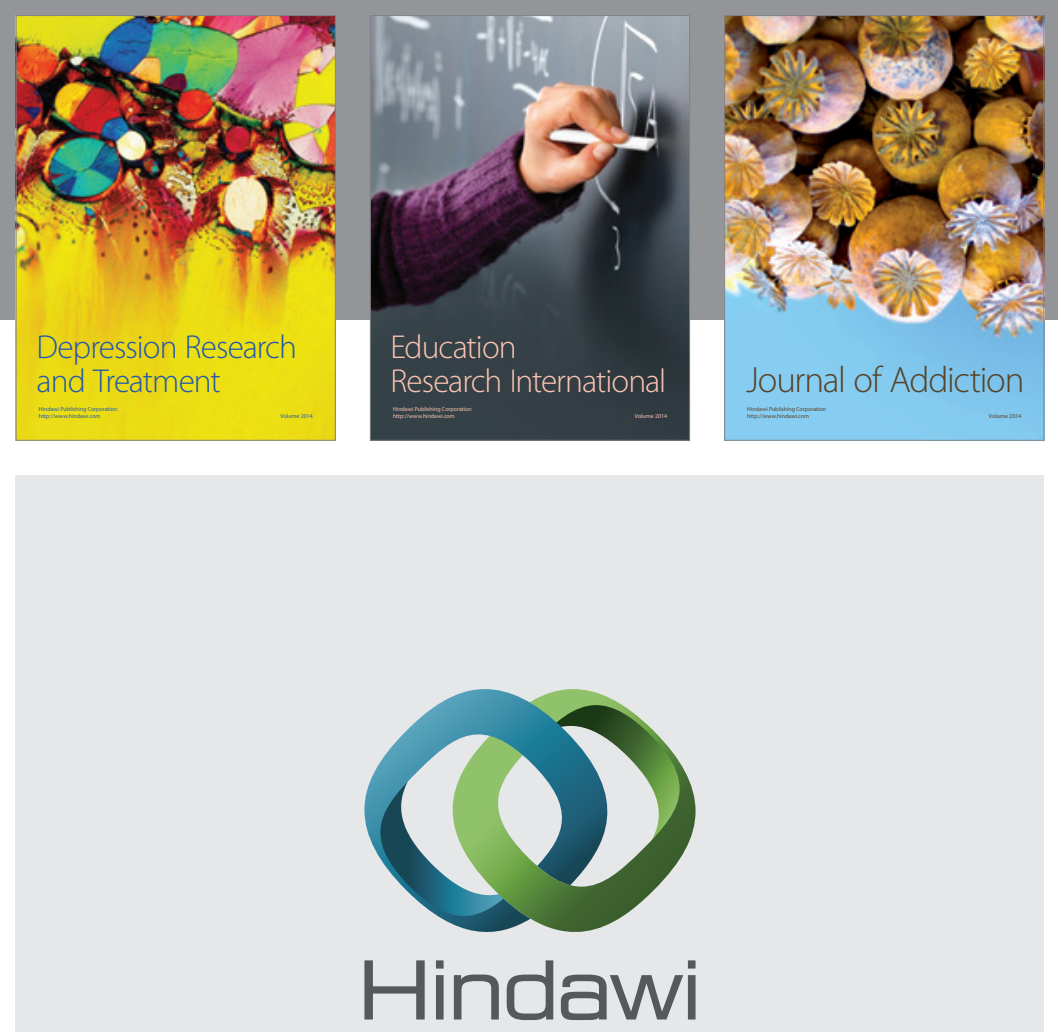

Submit your manuscripts at

http://www.hindawi.com

Child Development Research
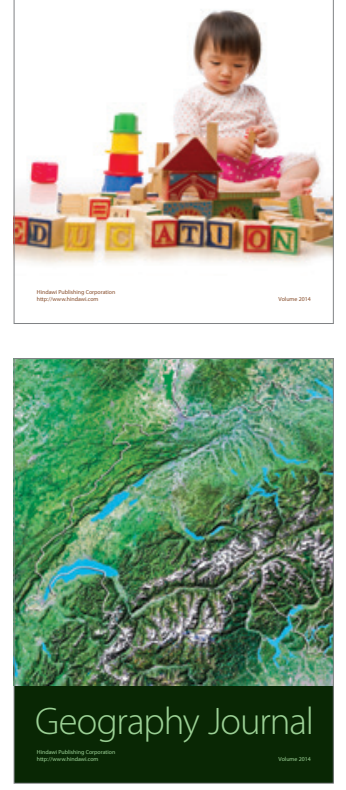

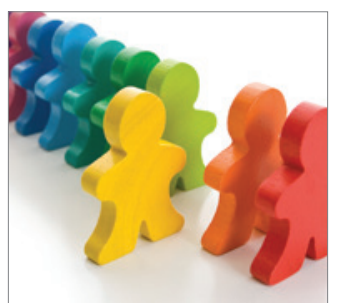

Autism

Research and Treatment
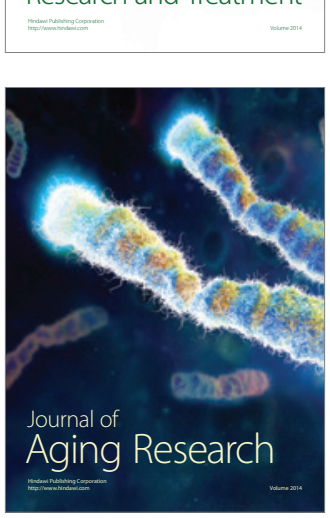
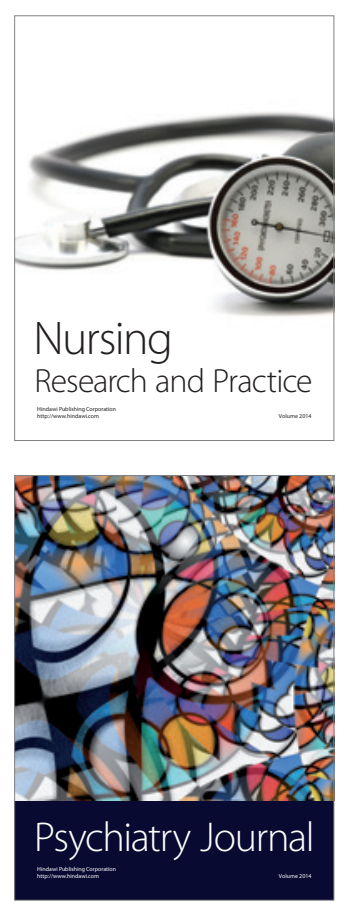
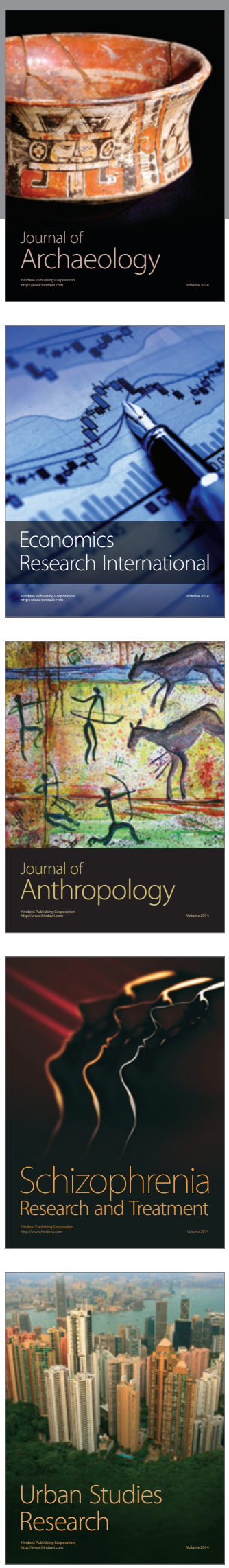